\title{
DA CIDADE DOS URBANISTAS À CIDADE DA GENTE? - A IMAGEM DE CURITIBA NA MÍDIA E A CONSTRUÇÃO DOS CENÁRIOS ELEITORAIS DE 2004 E 2008 ${ }^{1}$
}

\author{
Fábio Pendiuk ${ }^{2}$ \\ Nelson Rosário de Souza ${ }^{3}$
}

\begin{abstract}
Resumo: Diante da introdução de um novo perfil de liderança na capital paranaense, a partir da análise das imagens da cidade de Curitiba produzidas no discurso de seu principal periódico antes e durante as eleições de 2004 e 2008, acreditando ser este um importante elemento na construção dos Cenários de Representação da Política daqueles momentos, este artigo apresenta as principais características do comportamento da mídia ao longo dos processos de eleição e reeleição do atual prefeito. $\mathrm{O}$ artigo apresenta ainda o reflexo destes cenários nas campanhas eleitorais dos horários gratuitos de propaganda eleitoral.
\end{abstract}

Palavras-Chave: Mídia, Eleições, Cenários de Representação da Política.

Resumen: Delante de la introducción de un nuevo perfil de liderazgo en la capital de Paraná, a partir del análisis de imágenes de la cuidad de Curitiba producidas en su principal periódico antes y durante las elecciones de 2004 y 2008, creyendo que este es un importante elemento en la construcción de escenarios de representación política de estos momentos, este artículo presenta las principales características del comportamiento del diario en su cobertura de los procesos de elección y reelección del actual alcalde. El artículo presenta también el reflejo de estos escenarios en las campañas de los programas electorales gratuitos.

Palabras-claves: Medios de Comunicación, Elecciones, Escenarios de Representación Política.

Abstract: Facing the introduction of a new profile on leadership in the capital of Paraná, from analysis of Curitiba city images produced in speech of its main journal media before and during the city elections of 2004 and 2008, believing that to be an important element on the development of the political representation scenarios of those moments, this article presents the main features of the media behavior over the election and reelection process of the current mayor. The study also presents the reflection of these scenarios in the free televised election campaigns.

Key-words: Media, Elections, Scenarios of Political Representation

\footnotetext{
${ }^{1}$ Este artigo apresenta as principais conclusões das pesquisas realizadas por Fábio Pendiuk, sob orientação de Nelson Rosário de Souza, no decorrer dos cursos de doutorado e mestrado do Programa de PósGraduação em Sociologia da Universidade Federal do Paraná. Este trabalho conta também com o auxílio de diversos dados coletados pelos pesquisadores do Grupo de Estudos sobre Comunicação e Política do Departamento de Ciência Sociais da mesma universidade.

${ }^{2}$ Fábio Pendiuk é doutorando em Sociologia pela Universidade Federal do Paraná e pesquisador do Grupo de Estudos sobre Comunicação e Política do Departamento de Ciências Sociais da UFPR.

3 Nelson Rosário de Souza é doutor em Sociologia pela Universidade de São Paulo, professor e coordenador do Grupo de Estudos sobre Comunicação e Política do Departamento de Ciências Sociais da Universidade Federal do Paraná.
} 


\section{INTRODUÇÃo}

A atribuição do título de cidade modelo a Curitiba, fruto de uma estratégia de projeção da eficácia de seu planejamento urbano, implementado a partir da década de 70 e tomado como o carro chefe do discurso oficial de um mesmo grupo político ao longo das últimas gestões, transformou a "cidade modelo", "das inovações urbanísticas", na protagonista não só dos debates políticos, mas também do espaço reservado à cidade nos veículos de mídia locais. A produção desta imagem da cidade, apoiada na promoção dos feitos de seus gestores e na espetacularização da política de urbanismo, consolidou-se como identidade local e motivo de orgulho cívico entre seus habitantes, construindo uma representação do interesse dominante que contribuiu para legitimar a estabilidade hegemônica do grupo político dos urbanistas.

Marco da introdução de um novo perfil de liderança política na capital paranaense, as disputas para a prefeitura de Curitiba em 2004 e 2008 mostram-se como um terreno fértil para estudos sobre o cenário político local. O rompimento público do candidato e então vice-prefeito, Beto Richa (PSDB), com o prefeito Cássio Taniguchi (PFL), e sua vitória no segundo turno do processo eleitoral de 2004 abalou, aparentemente, o perfil tecnocrático dos últimos gestores, visto que o candidato do PSDB, apesar de ter sido vice-prefeito e receber o apoio de Jaime Lerner (PSB), líder dos urbanistas, não tinha origem naquele grupo, nem havia associado sua imagem ao planejamento urbano durante a campanha e, após eleito, adotado o mote "Curitiba, a Cidade da Gente" como slogan de sua administração, o que também indicava uma tentativa de mudar a imagem da cidade atrelada às administrações anteriores ${ }^{4}$. É possível que o cenário eleitoral anterior já apontasse para uma vontade de mudança, por parte do eleitorado, no perfil de liderança daqueles que exerciam a hegemonia na cidade desde $1970^{5}$, dado que nas eleições de 2000 a vitória não havia sido tão fácil quanto em eleições anteriores, tendo o crescimento do candidato da oposição, Ângelo Vanhoni (PT), surpreendido o grupo da situação ${ }^{6}$. Já em 2008, toda disputa foi marcada pelo continuísmo indicado pelas pesquisas que apontavam o prefeito, então candidato à reeleição, como o favorito das intenções de voto durante todo o processo

\footnotetext{
4 Vale sublinhar o grupo da situação estava, então, divido entre o candidato apoiado por Taniguchi, Osmar Bertoldi (PFL), que se apresentava como integrante daquele grupo, e Beto Richa (PSDB), apoiado por Lerner, que representava certa mudança no tipo de gestão realizada até aquele momento. É importante lembrar também que em 2004 o cenário político nacional estava ainda envolvido por um espírito de mudança com a vitória de Lula (PT) nas eleições presidenciais de 2002.

5 De 1970 a 2004, o grupo político de técnicos urbanistas, liderados pelo arquiteto Jaime Lerner (então filiado ao PDT) só não esteve à frente do executivo municipal entre 1983 e 1989, início do período de redemocratização, quando nas administrações de Maurício Fruet e Roberto Requião, ambos do PMDB.

${ }^{6}$ No primeiro turno das eleições de 2000, o candidato do grupo dos urbanistas, Cassio Taniguchi (PFL), teve $43,97 \%$ dos votos válidos, tendo Ângelo Vanhoni (PT) garantido sua ida para o segundo turno com $35,37 \%$ dos votos. No segundo turno Taniguchi vence a disputa com 51,48\% dos votos, contra 48,52\% de Vanhoni.
} 
eleitoral. Enquanto Beto Richa (PSDB) permaneceu com resultados entre $72 \%$ e $74 \%$ das intenções de voto e um índice de rejeição sempre abaixo de $7 \%$, sua principal concorrente, Gleisi Hoffmann (PT), não conseguiu superar a marca dos 20\% das intenções, mantendo uma rejeição em torno de $22 \%$. Ao final do processo, o candidato tucano venceu a eleição com 778.514 votos (77\%), conquistando a maior votação da história do município desde 1988, quando Jaime Lerner ficou com 57\% dos votos válidos7. Neste contexto, operando com uma definição mais ampla dos tipos de mensagens geralmente consideradas relevantes, indo além dos conteúdos explicitamente políticos, esta pesquisa pretendeu analisar o comportamento da mídia ao longo da cobertura dos temas referentes à cidade e aos principais candidatos da disputa eleitoral, com o objetivo de evidenciar sua importância no processo de construção desta conjuntura.

Quanto aos objetivos deste artigo, a partir do conceito de agenda-setting (McCOMBS \& SHAW, 1972), ou seja, de que os meios de comunicação de massa, mais do que determinar o que o público pensa, têm um papel crucial na indicação de quais são os temas importantes do momento, influenciando tanto os cidadãos comuns quanto o governo e a elite política, e do conceito de cenários de representação da política (LIMA, 1994), segundo o qual, em uma sociedade centrada na mídia, os meios de comunicação constroem elementos que, ao constituir nossas representações da realidade, definem e delimitam o espaço da realidade política. Buscou-se, através dos resultados da análise das imagens de Curitiba produzidas no discurso do principal jornal da cidade ao longo dos anos que antecedem as eleições municipais de 2004 e 2008, acreditando ser este um importante elemento na construção dos cenários de representação da política (CR-P) daquele momento, apresentar uma análise comparativa das principais notas conclusivas sobre a pesquisa dos tipos de cobertura feitos pelo jornal antes e durante os processos eleitorais e verificar a existência de uma suposta relação de influência entre o comportamento da mídia ao longo do período analisado e as estratégias discursivas de campanha apresentadas pelos candidatos à prefeitura no Horário Gratuito de Propaganda Eleitoral. Parte-se da hipótese de que o jornal Gazeta do Povo, nos diferentes contextos, teria construído CR-Ps distintos ao longo de sua cobertura dos temas referentes à cidade, cujos elementos se refletiram nos programas apresentados no HGPE de 2004 e 2008.

O texto a seguir estrutura-se em três partes. No primeiro capítulo são apresentadas as dimensões teóricas referentes à problemática desta análise. Presentes nesta construção conceitual estão os critérios de noticiabilidade, o conceito de agendasetting e, em especial, a produção de cenários de representação pela mídia e a

\footnotetext{
7 Fontes: Ibope, Datafolha e RPC/Gazeta do Povo.
} 
importância das imagens produzidas por ela na análise do momento político. $\mathrm{O}$ segundo capítulo destina-se a uma análise qualitativa da produção de imagens da cidade de Curitiba pela Gazeta do Povo durante os anos 2003, 2004, 2007 e $2008^{8}$ para verificar os tipos de coberturas feitas pelo jornal dos assuntos referentes à cidade nos diferentes períodos pré-eleitorais e, posteriormente, contrastar estas imagens às utilizadas pelos candidatos em suas estratégias de campanha. Finalmente, o terceiro capítulo trata da análise comparativa dos temas abordados nas campanhas apresentadas nos Horários Gratuitos de Propaganda Eleitoral de 2004 e 2008 com o cenário construído pela mídia impressa, buscando evidenciar uma suposta relação de influências entre estes canais de comunicação e esclarecer o papel da mídia na construção daquelas conjunturas.

\section{FUNDAMENTAÇÃO TEÓRICA}

Para que fique clara a perspectiva adotada na escolha do objeto e durante a análise do problema proposto aqui, é fundamental a revisão de algumas abordagens desenvolvidas no campo de estudos que tratam das relações entre a mídia e a política, precisamente, os conceitos utilizados aqui como ferramentas teóricas.

A maneira como a mídia se organiza e a compreensão de como se dá o processo de transformação dos acontecimentos e assuntos em notícias são de suma importância para uma interpretação eficaz de sua cobertura. Assim, para que seja compreendida a dinâmica da construção de agendas coincidentes e enquadramentos predominantes, que atuam direta ou indiretamente na formação da opinião pública, é necessário salientar, previamente, a lógica do processo produtivo de notícias nos meios de comunicação, onde se evidencia o estabelecimento de rotinas profissionais e de pressões exercidas pelos interesses das empresas de comunicação que condicionam o trabalho cotidiano dos jornalistas e exprimem determinados critérios no processo seletivo do que deve ou não tornar-se notícia.

Segundo Wolf (2005), a seleção dos fatos que serão noticiados é feita em relação a um conjunto de valores que incluem critérios profissionais e organizacionais, como a eficiência, a produção de notícias e o tempo disponível para seu tratamento, o que evidencia uma lógica de produção específica da mídia. Enquanto o público é pouco conhecido pelos jornalistas, o contexto profissional-organizacional-burocrático exerce

\footnotetext{
${ }^{8}$ A delimitação deste período para análise se deve ao fato de importantes temas abordados pela Gazeta do Povo, ao longo dos meses que antecedem à disputa eleitoral, terem a origem de suas ênfases em acontecimentos noticiados durante o primeiro semestre de 2003. Além disso, considera-se um período significativo para analisar o comportamento adotado pelo jornal e verificar a construção de um cenário de representação. Visando a comparação de cenários, o mesmo período (um ano e 10 meses que antecedem a disputa) também foi utilizado na análise do pleito seguinte.
} 
uma influência decisiva nas escolhas. Isso não significa que a imagem que os meios de comunicação têm de seus consumidores não tenha importância na escolha daquilo que se tornará ou não notícia, mas quando se trata de meios de comunicação de massa, onde boa parte das características do público não são uma constante, as exigências de produção, ou seja, as referências implícitas no grupo de colegas e no sistema de fontes prevalecem sobre as referências implícitas no público.

A partir desta abordagem, que já nos anos 50 exaltava a importância de uma sociologia dos emissores, os estudos sobre os critérios de noticiabilidade (newsmaking) passaram a levar em conta a questão da manipulação inconsciente produzida na cobertura informativa, relacionando as características de produção de cada meio com suas práticas profissionais e seus valores compartilhados e interiorizados, ao invés de reduzir todas as manipulações exclusivamente às pressões e influências externas. Neste sentido, características da organização do trabalho e elementos da cultura profissional definem o que é ou não notícia e legitimam o processo de produção indiferentemente da existência de tais forças externas, que poderiam estar encobertas nesse processo, o que também acabaria prevenindo as críticas de um público preocupado com a imparcialidade dos meios de comunicação. Assim, não sendo esta influência externa uma constante, o conceito de noticiabilidade deve, antes, ser entendido através de um complexo de requisitos - criados a partir dos pontos de vista da estrutura do trabalho nos aparatos informativos e do profissionalismo dos jornalistas - exigidos de cada evento para que ganhe o espaço público em forma de notícia (SOUSA, 1999).

Levando-se em consideração que parte do modus operandi do jornalista limita sua função ao relato de eventos, mas que o processo rotineiro de produção delimita seus critérios de seleção e tratamento destes eventos, conclui-se que os acontecimentos de maior noticiabilidade são aqueles que se apresentam passíveis de serem utilizados sem muitas alterações do ciclo de produção normal e que em algum ponto despertam o interesse do público. Porém, nada impede que, diante de eventos excepcionais, o aparato informativo tenha certa elasticidade para adaptar-se à situação. Revela-se, assim, uma perspectiva prática, voltada não apenas para a seleção de acontecimentos mais ou menos noticiáveis, mas também para a seleção do que é mais noticiável em um determinado evento para torná-lo atrativo aos espectadores. Surge aí o elemento valor notícia, que, segundo seu conceito, ao derivar de uma série de admissões implícitas e considerações de aspectos substantivos da notícia, aparece como indicador de quão interessante é um acontecimento para ser exposto no noticiário (SOUZA, 1999).

É importante também considerar que entre a seleção de um evento e sua publicação há um importante processo de hierarquização que determina o tratamento e o espaço deste no noticiário. Segundo Silva (2005), para compreender os critérios que 
levam um fato a ser considerado noticiável é necessário situar o conceito de valoresnotícia no universo mais amplo do conceito de noticiabilidade, levando-se em consideração a importância destes valores no tratamento hierárquico dado às notícias, ou seja, o valor de noticiabilidade de um fato pode estar nas possibilidades de tratamento dado a ele. Entende-se, assim, que os valores-notícia estão presentes não apenas na rotina de seleção das notícias, mas também permeando os procedimentos posteriores ao guiar, implícita ou explicitamente, o trabalho redacional e seus agentes, sugerindo o que deve ser enfatizado ou omitido na apresentação do material ao público e estabelecendo, desta forma, critérios de fácil e rápida aplicação diante da urgência em que se dá todo o processo.

Nota-se, então, que esta seleção não pode ser explicada como uma simples escolha feita de forma pessoal pelo jornalista, sendo necessário encará-la como um processo complexo desenvolvido durante todo o ciclo de trabalho, realizado com base em diferentes fatores, funções e valores organizacionais, e onde nem todas as motivações são reduzíveis à necessidade direta de escolher quais notícias serão difundidas. Visto desta maneira, tal processo se apresenta como uma dimensão objetiva que viabiliza a análise científica das posições assumidas pelos meios de comunicação de massa diante da seleção das notícias e do tratamento dado a elas, principalmente durante processos políticos, como, no caso desta pesquisa, o eleitoral, onde diferentes grupos poderiam ser explicitamente favorecidos com a seleção do que freqüentemente se torna ou não notícia, ou do que nesta é enfatizado.

Vale lembrar que, de toda essa complexidade, ainda que levadas em consideração as variações ligadas à diversidade do contexto e às diferenças organizacionais, pouco transparece no produto acabado. Assim, inúmeras restrições que aos poucos influenciam a escolha das notícias são apagadas por uma apresentação que intencionalmente se dá como o simples relato dos acontecimentos do dia.

Do mesmo modo que as rotinas de produção e os critérios de relevância em sua aplicação constante formam um quadro institucional e profissional onde os jornalistas percebem a noticiabilidade dos eventos, uma série de estudos específicos constatou que os meios de comunicação, ao enfatizar certos temas por um longo período, formam esquemas cognitivos em seus espectadores. Isso determina de maneira mais ou menos consciente o sentido dos eventos observados, o que trouxe grandes avanços para a compreensão do poder da mídia e de sua relação com diversas esferas da sociedade, principalmente a política. Neste contexto, porém retomando um argumento que se distanciava dos estudos culturais da época, surge o conceito de agenda-setting, desenvolvido pelos pesquisadores Maxwell McCombs e Donald Shaw (1972), que, ao testar empiricamente os efeitos da comunicação de massa na 
preferência política e eleitoral do público, sustentam, enquanto hipótese da análise, que o público tende a incluir ou excluir de seus conhecimentos aquilo que a mídia, em longo

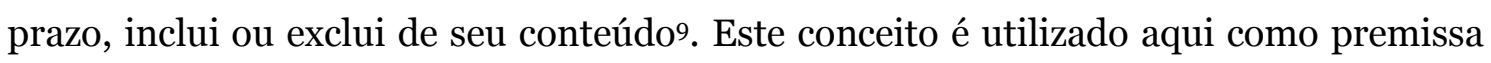
teórica que justifica o intuito da análise do comportamento da mídia e da relação de influência estabelecida entre a sua cobertura e as campanhas eleitorais para a prefeitura de Curitiba em 2004 e 2008.

A partir da afirmação de Bernard Cohen de que a mídia, na maioria das vezes, não obtém tanto sucesso em dizer como o público deve pensar quanto em que deve pensar, McCombs e Shaw (1972), em um artigo pioneiro, analisaram a capacidade da mídia de agendar discussões durante a campanha presidencial de 1968 nos Estados Unidos, verificando o que os eleitores da cidade de Chapel Hill, no norte da Califórnia, acreditavam ser os conteúdos mais importantes das campanhas para em seguida comparar com os assuntos cobertos por diversos meios de comunicação (revistas, jornais e televisão). Assim, os autores concluíram que a mídia havia realmente pautado os interesses daquele público, visto que o que não era preocupação antes passou a ser após a ênfase dada pelos meios de comunicação a determinados temas. Além disso, os autores evidenciaram, através de informações características do público entrevistado, que a mídia impressa influenciava mais aqueles que se interessavam por política do que a televisão e que tanto para os que se interessavam pouco por política, quanto para os interessados, o que mais influenciava não era diretamente os meios de comunicação, mas as conversas entre as pessoas. Esse fato não diminui a importância do papel da mídia nesta relação, mas ressalta a importância dos formadores de opinião. ${ }^{10}$

Entende-se por agenda-setting a capacidade da mídia de pautar a comunicação para além dela e influenciar a maneira como os acontecimentos são

\footnotetext{
9 Há uma discussão entre pesquisadores que acreditam que a teoria da agenda-setting seja um reforço dos efeitos poderosos dos meios de comunicação sobre seu público e aqueles que o tratam como um conceito filiado ao paradigma dos efeitos limitados (COLLING, 2001). Parte desta discussão tem início com o argumento de que quando o conceito de agenda-setting foi criado, a teoria dos efeitos limitados já havia conquistado um espaço significativo entre os estudos de comunicação e, ao retomar a idéia de que a mídia tinha um poder sobre seu público, o de pautar as discussões com temas colocados por ela, o conceito estaria reafirmando as antigas teses dos efeitos absolutamente previsíveis. Porém, o próprio McCombs (1996) afirma que suas pesquisas atestam os efeitos limitados ao revelarem que o poder de agenda nem sempre é verificado, havendo casos em que a opinião pública prevalece sobre a cobertura das notícias. Entende-se, assim, o conceito como uma ferramenta teórica para a análise dos efeitos da mídia. É importante registrar que esta pesquisa fundamenta-se no conceito de agenda-setting como hipótese, à maneira como foi colocada desde o início por McCombs e Shaw (1972), a partir da qual se baseia o estudo do comportamento de um veículo de mídia e sua suposta influência na propaganda eleitoral, e, portanto, não encara o agendamento como uma condição sine qua non, que desconsidera o poder de outros elementos ou agentes envolvidos, como o poder de negociação do público com o conteúdo vinculado na mídia, o papel dos formadores de opinião ou mesmo a possibilidade não haver um agendamento.

${ }_{10}$ Nota-se que os autores não haviam identificado um poder ilimitado e direto dos meios de comunicação sobre seu público, o que confirma o argumento do próprio McCombs (1996) de que sua pesquisa, mesmo identificando um poder de agenda, não seguia na contramão do paradigma dos efeitos limitados. Mostrase, assim, o poder de agenda dos meios de comunicação de massa como uma hipótese a ser sempre testada em diferentes casos.
} 
projetados na opinião pública. Desta forma, tratando-se de uma sociedade moderna, onde os meios de comunicação de massa assumem um importante papel como fonte de informação, pressupõe-se que a maneira como a realidade social é vista e encarada pela opinião pública é fornecida, em grande parte, pelos meios de comunicação de massa, devido a constante exposição do público a seu conteúdo e seu efeito cumulativo e de longo prazo. Ou seja, ao longo de sua cobertura, a mídia constrói quadros de referência que são utilizados pelos espectadores para interpretar os temas da agenda pública.

Segundo Hohlfeldt (2001), além da relação de influências entre a mídia e seus receptores, nota-se um interagendamento entre diferentes tipos de mídia evidenciados na hierarquia assumida pela mídia impressa sobre a mídia eletrônica, tanto pelo poder de agendamento do receptor em geral, devido a sua maior permanência e poder de introspecção através da leitura, quanto pela sua maior dinamicidade e flexibilidade para expandir a informação e complementá-la. De certa forma, justifica-se, assim, a análise a seguir, cujo objeto é a relação de agendamento que supostamente se daria entre dois canais de comunicação: a impressa e a propaganda eleitoral televisiva, entendida aqui como um tipo de mídia, apesar de sua origem distinta.

Um importante complemento à teoria do poder de agendamento público da mídia, considerado um segundo nível da teoria do agenda-setting e que aparece nesta pesquisa para analisar o tipo de cobertura dada pela mídia, é o conceito de framing ou enquadramento (McCOMBS at al, 1997). Utilizada inicialmente por Erwing Goofman em 1974 a expressão framing descrevia os esquemas interpretativos que permitem ao público identificar e classificar eventos e informações, facilitando o processo de construção de significados e perspectivas. Quando apropriada por pesquisadores dedicados à notícia, a expressão passou a ser caracterizada como esquemas de construção do conteúdo jornalístico (GAMSON, 1985). Segundo Gamson (1985), o que caracteriza o framing de notícias são os esquemas de seleção e ênfase aplicados no processamento da informação. Nestes termos, enquadrar seria selecionar alguns aspectos de um evento noticiável e torná-los mais salientes no texto comunicativo de modo a promover uma definição particular da interpretação, avaliação e/ou tratamento do tema por parte do público (ENTMAN, 1993).

Em outras palavras, o conceito de framing pressupõe que, ao salientar alguns aspectos de uma informação ou acontecimento, o jornalista determina $o$ enquadramento da notícia, promovendo uma definição particular do evento e indicando sua interpretação. A partir deste pressuposto, a análise da cobertura da mídia se volta não apenas para os temas abordados por ela, mas também para o tipo de ênfase dado a estes temas em cada notícia. Esta ênfase pode ser identificada nos discursos jornalísticos através da observação de imagens, metáforas, símbolos ou 
palavras-chave repetidas insistentemente ou em destaque para que se ressalte uma determinada idéia ou ponto de vista (PORTO, 2002).

Diante da suposição de que os enquadramentos permitem aos meios de comunicação e suas audiências organizarem e interpretarem temas e eventos políticos de forma específica e que as pessoas utilizam frequentemente os enquadramentos da mídia em discussões sobre eventos sociais e, principalmente, políticos, o conceito de enquadramento é utilizado neste artigo como ferramenta para verificar o tratamento dado aos temas mais recorrentes na Gazeta do Povo durante sua cobertura dos assuntos relativos à cidade de Curitiba. Acredita-se que a ênfase dada a determinados aspectos das notícias poderia ter forte influência sobre a forma como a imagem midiática da cidade foi refletida nas campanhas apresentadas no HGPE.

Outro fundamento teórico útil para explicar a relação de influência entre a mídia e o cenário político eleitoral analisada neste artigo é o conceito de Cenários de Representação da Política (CR-P) desenvolvido por Venício de Lima (1994) ${ }^{11}$. A partir da necessidade de compreender as representações da realidade na mídia através de uma articulação que situe essa questão num quadro de referência mais amplo das relações da mídia com a sociedade, Lima (1994) propõe uma superação da divisão mecânica entre as representações e a realidade, concebidas como áreas autônomas e distintas, defendendo que a representação não se refere apenas à existência de uma realidade externa que ela reflete, mas que ela é também parte constitutiva dessa realidade. De acordo com o autor, em uma sociedade centrada na mídia (media centric), como a atual, estas representações, construídas e reproduzidas nos meios de comunicação de massa, são a principal fonte de construção dos mapas cognitivos dos indivíduos. Segundo Lima (1994), atualmente, é nesse espaço midiático que surgem e se transformam as representações políticas, estéticas, de gênero, raça, gerações, entre outras. Define-se, assim, Cenários de Representação como o "espaço específico das diferentes representações da realidade, construído em processos de longo prazo na mídia e pela mídia” (LIMA, 2004, p. 14).

O autor elabora o conceito de Cenários de Representação da Política a partir do conceito de hegemonia de Gramsci ${ }^{12}$ retrabalhado por Raymond Willians (1979),

\footnotetext{
${ }^{11}$ A expressão "Cenário de Representação" foi utilizada pela primeira vez por Stuart Hall (1988) em um estudo sobre uma suposta mudança na política cultural negra na Inglaterra, onde o termo tinha o significado de subjetividade, identidade e política. Segundo Lima (2004, p. 10), "Hall não articulava diretamente a expressão com as diversas representações da realidade na mídia”. Já o conceito de Cenários de Representação da Política, desenvolvido por Lima (1994), foi melhor definido ao longo de uma série de artigos publicados pelo autor (LIMA, 1995, 1996, 1998, 2004).

12 Em Gramsci, a hegemonia é entendida como o direcionamento de uma sociedade através do qual se estabelece uma visão social de mundo e de convívio que faz a manutenção do poder dos dominantes. De acordo com o autor, a hegemonia de um grupo social se dá através do equilíbrio entre a sociedade política, que é formada pelo conjunto dos mecanismos através dos quais a classe dominante detém o monopólio legal dos aparelhos de coerção (o Estado, no sentido estrito, e suas ramificações), e a sociedade civil, formada pelos aparelhos privados de hegemonia, ou seja, pelo conjunto de organizações relativamente
} 
segundo o qual, hegemonia é um conjunto de práticas e expectativas que moldam as percepções que cada indivíduo tem de si mesmo e do mundo em que vive dentro do espaço das representações. Segundo Lima (2004, p. 14), para quem os cenários de representação são “o espaço específico das representações da realidade, constituído e constituidor, lugar e objeto da hegemonia”, o conceito gramsciano se destaca ao "relacionar a totalidade do processo social com distribuições específicas de poder e influência”. Diante de uma sociedade marcada por desigualdades (sociedade de classes), onde as relações de domínio e subordinação caracterizam o processo social como um todo, mostra-se fundamental acrescentar essa relação aos conceitos de hegemonia e cenários de representação dividindo-os em CR hegemônico e CR contrahegemônico ou alternativo. Assim, cenários de representação emergentes, que são construídos fora da mídia ou em mídias de menor audiência, mesmo que atinjam tardiamente a grande mídia, são considerados contra-hegemônicos. Existem também os elementos permanentes, que são anteriores aos CR-P hegemônico e contrahegemônico. Trata-se de elementos construídos pelo imaginário social e pela cultura que constituem o hegemônico antes dos cenários de representação. Conclui-se, assim, que estes elementos dificilmente são alterados, sendo mais duradouros do que os cenários de representação, que apresentam um caráter transitório na construção de diferentes conjunturas. É importante também considerar o impacto que a conjuntura econômica, social ou política pode provocar no CR-P dominante, caso estes elementos conjunturais evoquem elementos pré-existentes no imaginário social ou na cultura política durante o processo eleitoral.

Ao conceito de CR-P são introduzidas duas hipóteses relacionadas uma ao processo político como um todo e outra aos processos eleitorais. Segundo Lima (2004, p. 30), no que diz respeito ao processo político, embora não prescreva os conteúdos da prática, o CR-P dominante "demarca os limites dentro dos quais as idéias e os conflitos políticos se desenrolam e são resolvidos, podendo neutralizar, modificar ou incorporar iniciativas opostas ou alternativas”. Quanto ao processo eleitoral, o autor afirma que um candidato dificilmente vencerá as eleições se não ajustar a sua imagem pública ao CR-P dominante ou construir um CR-P alternativo. Dentre os pressupostos colocados pelo autor para a aplicação do conceito de Cenários de Representação da Política à compreensão e análise dos processos eleitorais, a que este artigo se interessa, destacase a disputa intra-hegemônica de interesses entre candidatos que defendem o CR-P

autônomas em relação ao Estado (meios de comunicação de massa, escola, igreja, sindicados, organizações profissionais, partidos políticos, etc.), responsáveis pela elaboração e difusão das ideologias do grupo social dominante. Visto desta forma, uma dominação consistente de uma classe sobre a outra não se dá necessariamente pelo uso da força, mas, principalmente, pela obtenção do consenso dos dominados, conquistado através da persuasão da opinião pública e da formação de uma esfera de valores, tanto na sociedade civil quanto na sociedade política, que legitime essa dominação (COUTINHO, 1999; GRUPPI, 1978). 
hegemônico, podendo ser esta uma disputa tanto entre classes quanto entre frações de um bloco histórico no poder ou entre candidatos que buscam uma nova articulação hegemônica (alternativa). Um exemplo disso são as disputas eleitorais de Curitiba, onde boa parte dos candidatos à prefeitura utiliza, de forma positiva, elementos do cenário de representação construído sobre a imagem do grupo hegemônico dos urbanistas.

A partir deste conceito, pretende-se analisar os temas que contribuíram para a construção de uma imagem midiática da cidade de Curitiba na Gazeta do Povo ao longo dos anos 2003, 2004, 2007 e 2008, com o intuito de revelar importantes elementos do Cenário de Representação da Política daquele momento, para, em seguida, investigar o uso destes nos discursos das campanhas apresentadas nos Horários Gratuitos de Propaganda Eleitoral, verificando, assim, uma suposta relação de influências entre o comportamento da mídia e a propaganda eleitoral.

Dentre as críticas feitas ao conceito de Cenários de Representação da Política, destaca-se o artigo de Jorge Almeida (1999), onde o autor, com base em pesquisas quantitativas e qualitativas do HGPE de 1994 e no estudo das telenovelas realizado por Porto (1995), dialoga criticamente com o conceito. Almeida (1999) sugere que os autores que baseiam seus estudos nos Cenários de Representação da Política subestimam o papel do Estado e da sociedade civil na construção dos cenários políticos. Segundo ele, ao concluir que os meios de comunicação são os principais construtores dos cenários que direcionam as campanhas eleitorais, Porto (1995) desconsidera a implantação da nova moeda como uma importante mudança no cenário político hegemônico identificado por ele. De acordo com Almeida (1999), as eleições de 1994 mostraram que a intervenção do Estado foi o principal fator para a alteração no cenário de representação da política, viabilizando a vitória de FHC. Visto isso, o autor lembra que para entender um cenário de representação é preciso verificar onde este cenário se realiza. Desta forma, para que um CR-P construído nos mídia seja considerado hegemônico, ele precisa se realizar na sociedade, ou seja, ser predominante não apenas nos meios de comunicação, mas também na opinião pública. É neste último caso que podem surgir outros atores e mediações capazes de alterar a maneira como um cenário identificado nos mídia se realiza na sociedade. O autor defende assim os estudos de recepção como um importante complemento para identificação dos cenários de representação. ${ }^{13}$ Também assim, Almeida (1999) enfatiza a importância de se

\footnotetext{
13 Mesmo acreditando na importância de um estudo da recepção do CR-P na opinião pública e aceitando o argumento de que uma série de mediações pode alterar a forma como as representações produzidas nos meios de comunicação são assimiladas pelo público, esta pesquisa limita-se a analisar o uso do cenário midiático pelos candidatos em suas tentativas de persuadir o eleitorado durante suas campanhas, visto que o objetivo aqui, não é comprovar a existência de um cenário de representação que interferiu no
} 
compreender o papel concreto do Estado, da sociedade civil e da mídia, e, principalmente, qual a direção das vias que ligam um ao outro na construção do hegemônico, em cada momento histórico e formação social, dada a diversidade de instrumentos com que cada um destes agrupamentos se utiliza para se manter ou chegar ao poder e assim construir ou reforçar cenários de representação hegemônicos.

É importante deixar claro que, para a análise proposta aqui, considera-se que os Cenários de Representação não são construídos exclusivamente dentro da relação dada entre a mídia e o receptor, muito menos considera esta uma via de mão única. Mesmo que os meios de comunicação de massa se mostrem capazes de criar fatos que se passem por reais sem se referir à existência de uma realidade externa, o que se deve a sua credibilidade, esta pesquisa não trabalha com tal hipótese, mas com a idéia de que os meios de comunicação, ao transformar acontecimentos isolados, e até mesmo opiniões isoladas sobre estes, em representações comuns, podem, ainda que levado em consideração o poder de negociação do público com o conteúdo apresentado pela mídia, torná-los parte do hegemônico através de sua ênfase em determinados temas e de seus respectivos enquadramentos. Ou seja, as mediações entre o que os meios de comunicação de massa enfatizam e a maneira como o público assimila tais informações não exclui a hipótese de que um cenário de representação construído na mídia possa ser fixado na opinião pública. É evidente também a necessidade de se levar em consideração fatos e acontecimentos que surgem fora dessa relação mídia-receptor, como é o caso do otimismo que envolvia o sucesso do Plano Real e sua influência na vitória de Fernando Henrique Cardoso nas eleições de 1994. ${ }^{14}$ É certo que uma série de relações causais podem ser estabelecidas na construção do cenário político eleitoral, mas para esta pesquisa, levando-se em consideração o contexto, o universo selecionado e os limites de seu objetivo, o conceito de CR-P se mostra plausível de ser utilizado como um fundamento teórico explicativo das relações analisadas a seguir.

\section{AS IMAGENS DA CIDADE NA MÍDIA}

A partir da análise da cobertura do Jornal Gazeta do Povo, quando este se referia à cidade de Curitiba, durante o período de janeiro de 2003 a outubro de 2004, e, posteriormente, entre janeiro de 2007 e outubro de 2008, precisamente um ano e dez meses que precederam as duas últimas eleições municipais, buscou-se identificar os elementos que contribuíram para a construção da imagem da cidade na mídia e o tipo

comportamento do eleitor, e sim esclarecer as relações de agendamento entre a mídia e a política através do estudo do comportamento da mídia e da fixação de suas representações no discurso político eleitoral.

14 É importante lembrar que, neste caso, os créditos da consolidação do cenário não foram exclusivos do Estado, visto que a mídia o havia reproduzido em sua programação. 
de cobertura dada aos temas envolvidos nesta construção, considerada aqui como um importante elemento do Cenário de Representação da Política eleitoral produzido na mídia, para que no capítulo seguinte sejam verificados seus reflexos nas campanhas políticas.

Através desta análise foi possível identificar uma série de elementos que construíram a imagem da cidade na mídia nos diferentes períodos e contextos. $\mathrm{O}$ quadro a seguir mostra os temas e enquadramentos que fizeram parte desta construção no primeiro período analisado.

Quadro 1 - a imagem da cidade: temas e enquadramentos de 2003 e 2004.

\begin{tabular}{|c|c|}
\hline TEMAS & ENQUADRAMENTOS \\
\hline Segurança & $\begin{array}{l}\text { 1. Crescimento dos índices de criminalidade; } \\
\text { 2. Escassez de policiais nas ruas; } \\
\text { 3. Descrédito das autoridades perante a população; } \\
\text { 4. Impasse político entre a prefeitura e o governo } \\
\text { do estado; } \\
\text { 5. Desqualificação do governo estadual. }\end{array}$ \\
\hline Saúde & $\begin{array}{l}\text { 1. Demora no atendimento das especialidades nos } \\
\text { postos de saúde; } \\
\text { 2. Agravamento do problema com o uso do sistema } \\
\text { de saúde pública por moradores de cidades } \\
\text { vizinhas; } \\
\text { 3. Necessidade de contratação de novos médicos; } \\
\text { 4. Situação melhor do que a de outras cidades. }\end{array}$ \\
\hline Habitação & $\begin{array}{l}\text { 1. Crescimento das favelas; } \\
\text { 2. Dificuldades de regularização das áreas de } \\
\text { invasão; } \\
\text { 3. Descaso do governo federal; } \\
\text { 4. Desqualificação do movimento dos sem-teto. }\end{array}$ \\
\hline Trânsito & $\begin{array}{l}\text { 1. Congestionamentos nas principais avenidas; } \\
\text { 2. Amenização do problema graças ao } \\
\text { planejamento urbano implantado a partir da } \\
\text { década de } 70 \text {. }\end{array}$ \\
\hline Transporte Coletivo & $\begin{array}{l}\text { 1. Aumentos consecutivos das tarifas; } \\
\text { 2. Impasse político entre a prefeitura e o governo } \\
\text { do estado; } \\
\text { 4. Desqualificação do governo estadual e federal. }\end{array}$ \\
\hline População & $\begin{array}{l}\text { 1. Aumento do número de imigrantes; } \\
\text { 2. Escassez de áreas habitáveis; } \\
\text { 3. Problemas comuns às grandes metrópoles; } \\
\text { 4. Amenização do problema graças ao } \\
\text { planejamento urbano. }\end{array}$ \\
\hline Impasse entre Partidos da Oposição & $\begin{array}{l}\text { 1. Desqualificação do grupo em prol de uma aliança } \\
\text { entre o PT e o PMDB para a formação de uma } \\
\text { chapa única de oposição. }\end{array}$ \\
\hline Administração Municipal & 1. Sucesso dos programas sociais da prefeitura; \\
\hline
\end{tabular}




$\begin{array}{ll}\text { Planejamento Urbano } & \begin{array}{l}\text { 2. O uso das soluções urbanísticas de Curitiba por } \\ \text { outras cidades do Brasil e do mundo (cidade } \\ \text { modelo). }\end{array} \\ & \begin{array}{l}\text { 1. Expectativas de melhorias com a construção do } \\ \text { Eixo Metropolitano de Transporte; }\end{array} \\ \text { 2. Melhorias conquistadas ao longo das últimas } \\ \text { gestões; } \\ \text { 3. Transformação de Curitiba em "cidade modelo". }\end{array}$

Fonte: $\mathrm{O}$ autor.

Entre os principais enquadramentos que construíram esta imagem ao longo de 2003 e 2004 destacam-se o (1) o crescimento da criminalidade, (2) as dificuldades de regularização das áreas de invasão, (3) a demora no atendimento das especialidades nas unidades de saúde e a necessidade de contratação de novos médicos, (4) os aumentos consecutivos das tarifas do transporte coletivo, (5) os impasses políticos entre a prefeitura e o governo do estado, (6) a desqualificação dos governos estadual e federal, (7) o sucesso do planejamento urbano e dos programas sociais da prefeitura e (8) o uso das soluções urbanísticas por outras cidades do Brasil e do mundo.

Ao longo da pesquisa deste primeiro período, evidenciou-se também a opção do jornal por trabalhar de forma crítica os temas que preocupavam a população e as autoridades locais, ainda que por uma via conservadora, de preocupação com a ordem e de ataque às esferas governamentais para além da esfera municipal, privilegiando as declarações dos representantes da gestão em curso, o que contribuía para a construção da imagem de uma cidade que passava por diversas dificuldades que tendiam a aumentar com seu inevitável crescimento nos próximos anos e a falta de apoio dos governos estadual e federal, mas que ainda conservava as qualidades de um bom lugar para se viver, graças às soluções urbanísticas implantadas pelas gestões anteriores e o sucesso de uma série de programas sociais da prefeitura que tinham o reconhecimento de seus habitantes e serviam de exemplo para outras cidades do mundo. Assim, mesmo apontando os pontos negativos da cidade, o grande número de matérias voltadas para as declarações dos órgãos municipais, que na maioria dos casos repassavam a responsabilidade dos problemas para outras esferas de governo e enfatizavam os resultados conquistados até o momento, construíam no jornal um Cenário de Representação da Política marcado pela imagem da "cidade modelo e dos urbanistas" construída ao longo das últimas gestões. 
Quadro 2 - a imagem da cidade: temas e enquadramentos de 2007 e 2008

\begin{tabular}{|c|c|}
\hline TEMAS & ENQUADRAMENTOS \\
\hline Planejamento Urbano & $\begin{array}{l}\text { 1. Grande número de projetos da prefeitura para o } \\
\text { sistema viário; } \\
\text { 2. Transtornos causados pelas obras do projeto } \\
\text { viário, atrelados à falta de planejamento; } \\
\text { 3. Insatisfação dos comerciantes com as obras; } \\
\text { 4. Necessidade de revitalização do centro; } \\
\text { 5. Necessidade de integração com a Região } \\
\text { Metropolitana; } \\
\text { 6. Expectativas em torno dos planos de metrô; } \\
\text { 7. Críticas dos ex-prefeitos (urbanistas) ao } \\
\text { planejamento (metrô, transporte e integração). }\end{array}$ \\
\hline Habitação & $\begin{array}{l}\text { 1. Onda de ocupações irregulares; } \\
\text { 2. Enchentes e problemas ambientais nas } \\
\text { ocupações às margens dos rios; } \\
\text { 3. Parceria entre Prefeitura e Governo Federal na } \\
\text { regularização e urbanização das ocupações. }\end{array}$ \\
\hline Trânsito & $\begin{array}{l}\text { 1. Caos: aumento dos congestionamentos atrelado } \\
\text { ao crescimento do número de carros nas ruas; } \\
\text { 2. Obras da prefeitura escoavam o trânsito, mas } \\
\text { causavam transtornos durante a execução; } \\
\text { 3. Imagem do prefeito atrelada às obras do projeto } \\
\text { viário; } \\
\text { 4. Uso da bicicleta como boa alternativa (ciclo } \\
\text { faixas). }\end{array}$ \\
\hline Segurança & $\begin{array}{l}\text { 1. Crescimento alarmante dos índices de } \\
\text { homicídios; } \\
\text { 2. Alto índice de assaltos no centro da cidade; } \\
\text { 3. Instalação de câmeras de monitoramento pela } \\
\text { prefeitura; } \\
\text { 4. Criação da Secretaria Municipal Anti-drogas } \\
\text { (lacunas no relacionamento com Secretaria } \\
\text { Estadual, falta de verba própria e dependência de } \\
\text { programas federais); } \\
\text { 5. Epidemia de Crack: Tráfico e violência atrelada } \\
\text { ao uso da droga na capital. }\end{array}$ \\
\hline Transporte Coletivo & $\begin{array}{l}\text { 1. O transporte coletivo estava saturado } \\
\text { (superlotação e necessidade de novas frotas); } \\
\text { 2. Demora na aprovação do projeto de licitação } \\
\text { para contratação de nova empresa de ônibus } \\
\text { (projeto traria poucas novidades aos usuários); } \\
\text { 3. Situação piora com a troca da frota antiga por } \\
\text { microônibus sem cobrador; } \\
\text { 4. Protestos e especulações sobre o passe livre } \\
\text { estudantil. }\end{array}$ \\
\hline Saúde & $\begin{array}{l}\text { 1. Região metropolitana satura hospitais da capital; } \\
\text { 2. Investimentos do SUS não acompanharam o } \\
\text { crescimento populacional da capital e da região } \\
\text { metropolitana. }\end{array}$ \\
\hline Educação & $\begin{array}{l}\text { 1. Falta de vagas nas creches municipais; } \\
\text { 2. Greve dos funcionários piora a situação; }\end{array}$ \\
\hline
\end{tabular}




\begin{tabular}{|c|c|}
\hline & $\begin{array}{l}\text { 3. Curitiba possui a melhor nota entre as capitais } \\
\text { em educação. }\end{array}$ \\
\hline População & $\begin{array}{l}\text { 1. Alto índice de crescimento da população; } \\
\text { 2. Dificuldade de acompanhar este crescimento em } \\
\text { infra-estrutura; } \\
\text { 3. Jovens da periferia se encontravam a margem } \\
\text { das oportunidades. }\end{array}$ \\
\hline Política & $\begin{array}{l}\text { 1. Impasses entre a prefeitura e o governo do } \\
\text { estado: troca de acusações; } \\
\text { 2. Desqualificação do governo estadual: falta de } \\
\text { repasses de verbas estaduais à capital; } \\
\text { 3. Casos de nepotismo e funcionária fantasma na } \\
\text { administração de Beto Richa; } \\
\text { 3. Especulações sobre possíveis candidatos e } \\
\text { alianças de 2008; } \\
\text { 4. Especulações sobre Beto Richa disputar as } \\
\text { eleições estaduais em 2010. }\end{array}$ \\
\hline
\end{tabular}

Fonte: $\mathrm{O}$ autor.

Dos enquadramentos apresentados no quadro acima, utilizados pelo jornal no período que antecedeu às eleições de 2008, o jornal destacou (1) o grande número de obras realizadas pela prefeitura no sistema viário - em especial as obras da Linha Verde $^{15}$, que escoaria o trânsito com um projeto tipicamente curitibano (alusão aos corredores de transporte com vias exclusivas para ônibus construídos pelas gestões anteriores), mas que vinham causando transtornos aos usuários durante sua execução, como engarrafamentos, confusões com as mudanças adotadas para viabilizar o trabalho e crises no comércio das regiões em obras -; (2) a onda de ocupações de regiões irregulares e as parcerias com o governo federal através do repasse das verbas do Programa de Aceleração do Crescimento (PAC) investidas pela prefeitura na regulação e urbanização das áreas de invasão; (3) os congestionamentos gerados pelo alarmante número de carros nas ruas e a viabilidade do uso da bicicleta como meio alternativo de transporte, abrindo espaço para crítica à falta de investimento em ciclo faixas pela prefeitura, (4) o crescimento do número de homicídios, que colocava Curitiba entre as capitais mais violentas do país, cuja maioria dos crimes não era solucionada, (5) o esgotamento do transporte coletivo, que não havia acompanhado o crescimento da cidade, (6) a superlotação dos hospitais da capital por moradores da região metropolitana diante dos investimentos desatualizados do Sistema Único de Saúde, (7) o esgotamento da capacidade das creches municipais, que acumulavam um déficit de

\footnotetext{
15 Projeto urbanístico financiado pelo Banco Interamericano de Desenvolvimento (BID) que visa à transformação do trecho urbano da antiga BR 116 em uma avenida que integraria as regiões leste e oeste da cidade, abrigando o sexto corredor de transporte de Curitiba. Vale ressaltar, que o projeto inicial havia sido apresentado ao BID ainda no governo anterior, pelo prefeito Cássio Taniguchi (PFL), porém com o nome de "Eixo Metropolitano".
} 
45 mil vagas e (8) a desqualificação do governo estadual em seu impasse com a prefeitura diante de acusações não comprovadas do governador Roberto Requião (PMDB) de que o prefeito Beto Richa (PSDB) havia sido beneficiado com verba estadual desviada do Departamento de Estradas de Rodagens do Paraná (DER) durante sua campanha estadual em 2002 e do corte de recursos estaduais à capital, colocando a população como a maior prejudicada pela crise entre as administrações.

A pesquisa deste segundo período evidenciou interessantes mudanças na cobertura dos assuntos referentes à cidade ao se verificar uma ênfase maior em outros temas, como os que envolviam o sistema viário da cidade, além de dar outro tratamento a eles ao deixar de privilegiar as declarações dos órgãos municipais, abrindo espaço para que especialistas de diferentes áreas também opinassem sobre as questões que envolviam a cidade. Desta forma, pesquisadores e professores das principais universidades da capital expunham suas opiniões, proporcionando um maior aprofundamento no debate dos temas. Estes, por sua vez, davam um tom mais crítico ao conteúdo das matérias ao afirmarem que a revitalização do centro da cidade esbarrava na falta de segurança, que o planejamento urbano vinha sendo forjado pelos grandes shoppings, que as soluções propostas pela administração municipal para evitar os congestionamentos teriam alternativas mais eficazes e menos custosas, que as causas sociais da violência não eram atingidas com as medidas paliativas adotadas pela prefeitura, que os jovens da periferia se apresentavam como uma população em déficit à margem das oportunidades e que a função das instituições era desrespeitada diante da crise política que se estabelecia entre o governo estadual e a prefeitura. Outro fato que chamou a atenção na análise deste período é o espaço dado às declarações feitas pelos ex-prefeitos de Curitiba, membros do grupo político dos urbanistas, sobre o planejamento urbano da cidade. Jaime Lerner afirmava que o projeto do metrô era apenas uma fachada para angariar votos durante as eleições, já que, segundo ele, era inviável, enquanto Cássio Taniguchi (PFL) apontava para a necessidade de reestruturar o transporte coletivo e de investimentos em inovações para resgatar o orgulho do cidadão e Rafael Greca (PMDB) apostava em um metrô maior do que o projetado, fazendo uso de energias alternativas, e na integração com as cidades vizinhas, com a criação de uma rede metropolitana de serviços para salvar os mananciais de água da Região Metropolitana de Curitiba. Isso mostra que, apesar de ganhar um tom mais crítico à administração municipal e aos problemas que a cidade vinha enfrentando e ressaltar elementos que desconstruíam a imagem da cidade modelo, cujo crescimento saturou sua infra-estrutura de vanguarda, o cenário hegemônico ainda sofria influências das opiniões dos urbanistas. Trata-se, portanto, de um cenário com elementos mais propícios ao fomento do debate dos temas em pauta durante as 
campanhas e que também fornecia mais munição para a oposição durante as campanhas do que o cenário identificado no período analisado anteriormente.

\section{AS CAMPANHAS DO HGPE}

A partir da análise dos temas abordados nos Horários Gratuitos de Propaganda Eleitoral da televisão pelos principais candidatos à prefeitura de Curitiba em 2004 e 2008, buscou-se identificar as características de cada campanha e o uso dos elementos que vinham construindo a imagem da cidade na mídia nos anos que antecedem os pleitos, a fim de esclarecer suas relações de agendamento e identificar as características próprias de cada disputa.

Verificou-se, a partir dos dados coletados, que o CR-P construído na Gazeta do Povo se repercutiu de forma heterogênea no HGPE de 2004, visto que os candidatos haviam enfatizado diferentes elementos daquele cenário. Temas como segurança (Ângelo Vanhoni), saúde (Beto Richa), planejamento urbano (Osmar Bertoldi) e transporte coletivo (Mauro Moraes) eram tratados através dos mesmos enquadramentos utilizados pelo jornal. Houve também a tentativa de inverter alguns enquadramentos que favoreciam o grupo político da situação. É o caso do programa de Ângelo Vanhoni (PT), onde o impasse político entre a prefeitura e o governo do estado e a atribuição do título de cidade modelo a Curitiba, eram utilizados pelo candidato da oposição na tentativa de favorecer sua campanha ao alegar que a cidade carecia de uma integração com a administração estadual e que deveria continuar a dar exemplos, mas como “cidade da paz". Nota-se, ainda, que a ênfase dada à questão da saúde durante a propaganda eleitoral, principalmente no programa de Beto Richa (PSDB), conseguiu pautar o tema na Gazeta do Povo, que não o abordava desde julho de 2003. Ao adotar a saúde como um dos motes de sua campanha, o candidato do PSDB, mesmo tendo se ajustado ao elemento menos explorado na construção da imagem da cidade, havia contribuído para que o tema voltasse a se destacar na imprensa, fazendo com que a necessidade de melhorias no atendimento dos postos de saúde, apontadas em seu programa, fosse reforçada pela Gazeta do Povo durante o período eleitoral.

Outra evidência é o caráter personalista dos programas apresentados no HGPE, dado que os candidatos haviam utilizado menos da metade de seus tempos de propaganda no tratamento de suas propostas, que eram apresentadas em programações repetitivas e, muitas vezes, de forma superficial, optando pela ênfase na imagem do candidato, quase sempre baseada em argumentos vagos sobre suas qualidades pessoais, como a herança política de Beto Richa, filho do ex-governador José Richa, a posição de Mauro Moraes ao lado dos oprimidos e a confiabilidade de 
Rubens Bueno, que não havia enfatizado proposta alguma durante seu programa, limitando-se a promover sua imagem e pedir votos. Um personalismo que fora reproduzido na imprensa em uma cobertura apática e descritiva do dia-a-dia das campanhas, voltada mais para a agenda dos candidatos do que para suas propostas de governo ${ }^{16}$, e que aproxima o cenário eleitoral de uma das características do tipo ideal de democracia de público, desenvolvido por Manin (1995), no qual as campanhas seriam construídas sobre qualidades pessoais dos candidatos e promessas vagas.

Já a análise das campanhas de 2008 mostrou que, apesar do uso dos elementos do Cenário de Representação construído no jornal ter sido heterogêneo, como em 2004, com os candidatos enfatizando diferentes temas referentes à cidade durante suas campanhas, algumas particularidades daquela disputa podem ser destacadas. Beto Richa (PSDB), que havia ficado com a maior fatia do horário eleitoral, graças a sua coligação composta por dez partidos com significativa força política na capital ${ }^{17}$, enfatizou o tema da Habitação, utilizando a seu favor elementos do CR-P, como seu bom relacionamento com o Governo Federal no atendimento aos problemas que a cidade vinha enfrentando com a infra-estrutura nas áreas de ocupação irregulares, apresentando propostas para continuar a parceria e atender necessidades dos moradores das favelas. Richa também utilizou um espaço significativo de sua campanha para tratar das creches, afirmando que os problemas de vagas, alertado por ele que seriam muito citados por seus adversários, eram fruto do alarmante crescimento populacional da capital, propondo então a ampliação do atendimento às crianças curitibanas ao priorizar a educação infantil em seu próximo mandato. Sua principal adversária, Gleisi Roffmann (PT), priorizou os temas da Saúde e da Educação, afirmando que a prefeitura havia feito muitas obras, mas deixado de atender as necessidades essenciais da população, o que ficava evidente com a demora no atendimento das especialidades e a falta de vagas nas creches. Já Reitor Moreira (PMDB, partido do governador do estado) havia adotado uma postura mais tecnicista ao enfatizar o tema do Planejamento Urbano através do apoio do governo estadual. $\mathrm{O}$ candidato do PMDB dizia ter propostas para o planejamento criadas por grupos de técnicos experientes e competentes que haviam elaborado um programa de seis eixos de integração urbana (centros de bairros, centro de convívio jovem, cidade conectada, plano de mobilidade urbana, linha verde e integração metropolitana), além da proposta de construção de um metrô elevado, maior do que o proposto pela prefeitura e movido

16 Ver PENDIUK, F. e SOUZA, N. R. Cenário Político Curitibano: A introdução de um novo perfil de liderança. Anais do I Seminário Nacional de Sociologia \& Política da UFPR, Curitiba, Setembro de 2009.

17 A coligação do PSDB com PP, PSL, PDT, DEM, PSB, PR, PSDC, PRP e PTN garantiu ao candidato à reeleição o tempo de 11 minutos e 47 segundo em cada bloco, o que representa mais do que o dobro de sua principal adversária, Gleisi Hoffmann (da coligação do PT com PTC, PHS, PMN, PRB e PSC), que ficou com 5 minutos e 11 segundos. 
à energia elétrica fornecida em parceria com a Companhia Paranaense de Energia (COPEL), cuja construção não atrapalharia a vida da cidade. O peemedebista contava ainda com as declarações de apoio do arquiteto e urbanista Forte Neto (PMDB), expresidente do Instituto de Pesquisa e Planejamento Urbano de Curitiba, o IPPUC, antigo reduto de origem dos ex-prefeitos urbanistas.

Quanto aos candidatos nanicos, Maurício Furtado, do PV, enfatizou o transporte e o meio ambiente, afirmado que a cidade não era mais referência nesses temas, adotando como mote de campanha o lema "menos carros e mais bicicletas", para uma cidade ambientalmente sustentável. Fábio Camargo, do PTdoB, se apresentava como o prefeito dos bairros, afirmando que a prefeitura havia priorizado apenas o centro da cidade, criticando o projeto de revitalização do centro. Bruno Meirinho, do PSOL, priorizava a construção de uma cidade sem exclusão social, enfatizando sua luta por uma "cidade sem catracas", que selecionavam e separavam a população. Em seu programa Meirinho criticava o "Mito da Cidade Modelo", acusando o planejamento urbano de valorizar áreas nobres da cidade, excluindo a periferia e os municípios da região metropolitana. Já, Ricardo Gomyde, do PCdoB, apresentava uma proposta muito distante do CR-P construído no jornal ao apresentar seu projeto de criação de uma Secretaria Municipal da Juventude que valorizaria o esporte na capital fazendo parcerias com os clubes da cidade.

Ao contrário das campanhas de 2004, em 2008 mais candidatos nanicos utilizaram parte do seu tempo no HGPE para abordar temas propositivos, que, por sua vez, apresentavam os mesmos enquadramentos do CR-P construído na Gazeta do Povo, chegando, muitas vezes, a utilizar imagens das páginas do próprio jornal para enfatizar suas declarações. Porém, assim como no pleito anterior, a imagem dos candidatos ainda era priorizada, reafirmando o caráter personalista das campanhas ao apresentar Beto Richa como o melhor prefeito do Brasil e que aprendeu com o pai a ouvir as pessoas, Gleisi Hoffmann como cristã e experiente administradora pública graças às secretarias que havia assumido em Londrina e no estado do Mato Grosso do Sul, Reitor Moreira como médico preocupado com as pessoas e dotado de conhecimento técnico para planejar e fazer de Curitiba uma cidade a frente de seu tempo, Fábio Camargo como o deputado-vereador que fala diretamente com população dos bairros, Maurício Furtado como ambientalista e Ricardo Gomyde como o experiente ex-secretário estadual dos esportes.

A análise da relação de influências entre a mídia impressa e o conteúdo discursivo dos programas apresentados no horário eleitoral de 2004 e 2008 mostra que, guardadas as suas diferenças, os CR-Ps construídos na Gazeta do Povo haviam se repercutido nos programas dos candidatos, ao mesmo tempo em que o cenário 
personalista construído por suas campanhas pouco propositivas era reproduzido pelo jornal em uma cobertura descritiva da disputa.

\section{CONCLUSÃo}

A análise da cobertura dos temas que se referiam à cidade de Curitiba durante um ano e dez meses que antecederam as eleições municipais de 2004 e 2008 no jornal Gazeta do Povo permitiu identificar uma série de temas e enquadramentos que, ao longo deste período, construíram uma imagem midiática da cidade, entendida aqui como um importante elemento do Cenário de Representação da Política daqueles momentos.

$\mathrm{O}$ aumento da criminalidade associado à escassez de policiais nas ruas e ao descaso das autoridades estaduais diante de um impasse político com a prefeitura, a demora no atendimento das especialidades nos postos de saúde atribuída à escassez de médicos, a crise no sistema de transporte coletivo causada pelos aumentos consecutivos no valor das tarifas e o sucesso do planejamento urbano implantado nas últimas gestões, são alguns dos principais assuntos enfatizados durante 2003 e 2004 no jornal, que havia adotado em sua cobertura um viés conservador, de preocupação com a ordem e de ataque aos governos estadual e federal, privilegiando as declarações de representantes da administração municipal. Um comportamento que desfavorecia um debate para além daqueles argumentos e que contribuía para a construção da imagem de uma cidade que passava por diversos problemas comuns a grandes metrópoles, mas que ainda conservava a qualidade de vida proporcionada pela eficácia do planejamento urbano e de uma série de programas sociais que transformavam Curitiba em modelo para outras capitais, o que favorecia o grupo político que administrava a cidade há 16 anos. Evidencia-se, assim, um Cenário de Representação marcado pela boa imagem do grupo dos urbanistas, que havia se divido em duas candidaturas na eleição para prefeito de 2004.

Quanto à influência deste cenário nas campanhas eleitorais, o resultado da análise dos discursos apresentados no HGPE de 2004 mostra que os candidatos enfatizaram diferentes elementos da imagem da cidade construída na Gazeta do Povo. Os enquadramentos que construíram esta imagem se destacavam entre os principais argumentos dos candidatos durante a propaganda eleitoral, visto que cada um deles havia adotado um dos temas enfatizados na mídia como carro chefe de sua campanha, com exceção do candidato do PPS, Rubens Bueno, que se limitou a utilizar seu tempo de propaganda para divulgar sua imagem e pedir o apoio dos eleitores. Assim, a questão da segurança era enfatizada no programa de Ângelo Vanhoni (PT) em 
propostas que se referiam ao aumento dos índices de criminalidade e aos impasses entre a prefeitura e o governo do estado, numa tentativa de utilizar, a seu favor, elementos de um CR-P que desqualificava a administração de seus principais aliados, o governador do estado e o presidente da república. O tema da saúde, adotado como mote de campanha pelo PSDB, era abordado em propostas que tratavam dos mesmos problemas enfatizados no jornal em 2003 e após o início das campanhas no horário eleitoral. O planejamento urbano, associado na mídia ao grupo dos urbanistas, era enfatizado no programa de Osmar Bertoldi (PFL) em propostas que dariam continuidade aos projetos que haviam transformado Curitiba na cidade modelo, apresentando-se com o mesmo perfil tecnocrático dos últimos gestores ao tratar da construção do Eixo Metropolitano como sua principal promessa de campanha. Já o tema do transporte coletivo era diariamente abordado no programa de Mauro Moraes (PL) em sua principal promessa de campanha, a redução da tarifa, o que remetia à ênfase dada pela Gazeta do Povo aos últimos aumentos. Percebe-se, assim, a influência daquele cenário na construção das campanhas eleitorais.

Evidenciou-se também o caráter personalista dos programas, visto que os temas propositivos correspondiam a menos da metade do tempo destinado a cada candidato no HGPE. Temas algumas vezes abordados com propostas pouco detalhadas ou nada inovadoras que davam um tom superficial às promessas de campanha. No geral, as propagandas eleitorais reservavam um espaço muito mais significativo à imagem dos candidatos, baseando-se em argumentos vagos sobre suas qualidades pessoais, como no caso de Beto Richa (PSDB), cuja imagem era associada à figura do pai, de quem havia herdado a capacidade política, ou do programa de Rubens Bueno (PPS), que não havia feito muito mais do que apresentá-lo como uma pessoa de confiança. Construía-se, assim, um cenário eleitoral marcado por campanhas pouco interessadas em debater propostas para os problemas enfrentados pela cidade.

Quanto à análise da cobertura da cidade feita pelo jornal durante 2007 e 2008, ficou evidente a construção de um CR-P marcado por enquadramentos que revelavam uma postura mais crítica, de aprofundamento no debate dos problemas que a cidade vinha enfrentando, o que foi proporcionado pela abertura de espaço às declarações de especialistas em diversas áreas dos temas tratados. Assim, temas como planejamento urbano, trânsito, transporte coletivo, educação e impasses políticos eram abordados com diferentes vieses que, por vezes, se opunham ao discurso dos órgãos municipais, o que possibilitava uma reflexão mais aberta e mais rica em argumentos dos temas do que no período analisado anteriormente, o que acabou se repercutindo da mesma forma nas campanhas apresentadas no HGPE de 2008, apesar do uso diferenciado dos temas e enquadramentos do CR-P pelos candidatos. Neste contexto, a campanha da 
candidata do PT, Gleisi Hoffmann, que dividiu a prioridade dos temas entre saúde e educação, utilizando para o primeiro um enquadramento do cenário eleitoral anterior, a demora no atendimento das especialidades, e para o segundo o problema das vagas nas creches, um elemento enfatizado no cenário mais recente. Reitor Moreira, candidato do $\mathrm{PMDB}$, que, de acordo com o cenário construído na mídia, tinha o apoio do histórico rival da prefeitura nos impasses político, adotara um discurso tecnicista, que até a eleição anterior era a principal característica dos candidatos urbanistas, ao enfatizar em seu programa o planejamento urbano com a proposta de implantação de eixos de integração urbana que não causariam os mesmo problemas das obras da prefeitura durante suas execuções. Maurício Furtado, do PV, mostrava um transporte coletivo saturado, que já não era referência para outras cidades e apontava a abertura de ciclo faixas nas principais avenidas da cidade, exatamente como o tema havia sido enfatizado no jornal. Bruno Meirinho, do PSOL, priorizava seu espaço às críticas ao "mito" da cidade modelo, que havia excluído a periferia e a região metropolitana de seu planejamento. Já Fabio Campana, do PTdoB, criticava o projeto de revitalização do centro, abordando o tema de maneira oposta aos enquadramentos do jornal.

A partir das análises apresentadas neste artigo, conclui-se que os elementos da imagem da cidade construída no jornal Gazeta do Povo ao longo de 2003, 2004, 2007 e 2008, haviam se repercutido nos discursos apresentados nos Horários Gratuitos de Propaganda Eleitoral das últimas duas disputas pela prefeitura, ao mesmo tempo em que suas campanhas pouco propositivas contribuíam para que esta relação fosse consolidada através de um Cenário de Representação da Política marcado por um caráter conservador e favorável ao grupo político da situação em 2004 e, já em 2008, um cenário com caráter mais crítico e favorável ao debate dos temas que envolviam os problemas que a cidade vinha enfrentando nos últimos anos, o que resultou em uma maior exploração dos temas apontados pela mídia nos programas da oposição. Pode-se dizer, ainda, que se o vencedor da disputa de 2004, Beto Richa (PSDB), era o candidato que melhor se adaptava aos cenários políticos da época, visto que havia ajustado sua campanha a uma das questões enfatizadas pela mídia, contribuindo para que o tema, tomado como carro chefe de suas propostas, fosse realçado na imprensa durante o período eleitoral, além de receber o apoio do líder dos urbanistas, enquanto se apresentava com um perfil diferente daquele adotado pelos últimos gestores, o que remetia a um espírito de mudança no qual estava envolvido o cenário político nacional diante da recente vitória do Partido dos Trabalhadores nas eleições presidenciais de 2000. No pleito de 2008, Richa, além de entrar na disputa com a grande maioria das intenções de voto e compor uma forte coligação de dez partidos, o que lhe garantiu o dobro de espaço de sua principal adversária no HGPE, foi o candidato que melhor 
adaptou sua campanha ao cenário construído no principal periódico da cidade, ao não tentar negar a existência dos problemas da cidade, priorizando em seu discurso um elemento que já lhe era favorável e que remetia também a seu favor um trunfo da candidata adversária, o apoio do governo federal.

\section{REFERÊNCIAS BIBLIOGRÁFICAS}

ALMEIDA, Jorge. Dialogando criticamente com o conceito de CR-P. Anais do GT de Mídia e Política do $8^{\circ}$ Encontro Anual da Compós, UFMG, Belo Horizonte, 1999.

CERVI, Emerson e FUCKS, Mário. A cobertura da mídia impressa nas eleições municipais de Curitiba 2000. In: CARVALHO, Rejane V. A. de. A produção da política em campanhas eleitorais: Eleições Municipais de 2000, p. 39-68. Fortaleza: Pontes, 2003.

COHEN, B. C. The Press and Foreign Policy. Princenton: Princenton University Press, 1963.

COLLING, Leandro. Agenda-setting e framing: reafirmando os efeitos limitados. Porto Alegre: Revista Famecos, n.14, abril, 2001.

COUTINHO, Carlos Nelson. Gramsci: um estudo sobre seu pensamento político. Rio de Janeiro: Civilização Brasileira, 1999.

ENTMAN, Robert M. Framing: toward classification of a fractured paradigm. Journal of Communication, v. 43, n.4, p. 51-58, 1993.

GAMSON, William. Goffman's Legacy to Political Sociology. Theory and Society, Vol. 14, No 5, p. 605-622, 1985.

GRAMSCI, Antonio. Os intelectuais e a organização da cultura. Rio de Janeiro: Civilização Brasileira, 1995 .

HOHLFELDT, Antonio. Hipóteses Contemporâneas de Pesquisa em Comunicação. In: Hohlfeldt, A.; Martino, L.; França, V. (Org.). Teorias da Comunicação: Conceitos, Escolas e Tendências, p. 187-240. Petrópolis: Editora Vozes, 2001.

LIMA, Venício A. de. Televisão e Poder: A Hipótese do Cenário de Representação da Política: CR-P. Revista Comunicação \& Política, Nova Fase, Vol. 1, n.1, ago.- nov., 1994.

CR-P: novos aspectos teóricos e implicações para a análise política. Revista Comunicação \& Política, Rio de Janeiro, vol. I, n.1, 1995.

Cenário de Representação da Política, CR-P: um conceito e duas hipóteses sobre a relação dos mídia com a política. Anais do $10^{\circ}$ Encontro Anual da Anpocs, Caxambu, 1996.

Os mídia e a representação da política. In: ALMEIDA, Jorge e CANCELLI, Vitória (Orgs). Estratégia, luta política além do horizonte visível. São Paulo: Fundação Perseu Abramo, 1998. 
Cenários de Representação Política, CR-P. In: RUBIM, Antônio Albino Canelas (Org.), Comunicação e Política, p. 9-40. São Paulo: Ed. Unesp, 2004.

MANIN, Bernard. As metamorfoses do governo representativo. São Paulo: Revista Brasileira de Ciências Sociais, n. 29, ano 10, p. 5-34. São Paulo: Anpocs, 1995.

McCOMBS, Maxwell E. e SHAW, Donald L. The agenda-setting function of mass media. New York: Public Opinion Quarterly, vol. 36, nº 2, p. 176-187, 1972.

McCOMBS, Maxwell E. Influências de las notícias sobre nuestras imágenes del mundo. In: BRYANT, Jennings e ZILLMANN, Dolf (eds.), Los efectos de los medios de comunicación: investigaciones y teorias, p. 13-34. Barcelona: Paidós Ibérica, 1996.

McCOMBS, Maxwell; LOPES-ESCOBAR, Esteban e REY, Federico. Candidate images in Spanish elections: second-level agenda-setting effects. Journalism \& Mass Communication Quarterly, 74, p. 703-717, 1997.

PORTO, Mauro. A Mídia brasileira e a eleição presidencial de 2000 nos EUA: a cobertura do jornal. Folha de S. Paulo. Cadernos do CEAM, Ano II, n. 6, p. 11-32, 2001. Set. 2002.

Enquadramentos da mídia e política. Salvador: Anais da INTERCOM,

SOUSA, Jorge Pedro. As notícias e os seus efeitos. As teorias do jornalismo e dos efeitos sociais dos media. Lisboa: Universidade Fernando Pessoa, 1999. Disponível em: BOCC (Biblioteca On-line de Ciências da Comunicação) <http://www.bocc.uff.br/pag/_texto.php?html2=sousa-pedro-jorge-noticiasefeitos.html>.

WILLIAMS, Raymond. Marxismo e Literatura. Rio de Janeiro: Zahar, 1979.

WOLF, Mauro. Teorias das comunicações de massas. $2^{\mathrm{a}}$ ed. São Paulo: Martins Fontes, 2005. 